\title{
Future and Prospect use of Pyrethrum (Chrysanthemum cinerariifolium) as Part of the Integrated Pest and Disease Management (IPDM) Tool in Turkey
}

\author{
Flavien Shimira ${ }^{1, a, *}$, Senem Uğur ${ }^{1, b}$, Şamil Muhammet Özdemir ${ }^{1, c}$, Yeşim Yalçın Mendi ${ }^{1, d}$ \\ ${ }^{1}$ Department of Horticulture, Faculty of Agriculture, Çukurova University, 01330 Adana, Turkey \\ *Corresponding author
}

\section{A R T I C L E I N F O A B S T R A C T}

Review Article

Nowadays, immediate environmental friendly solutions such as the use of biopesticides and other methods to control and manage pests are well needed. They are imperative due to the continuous accumulation of toxic residues from synthetic insecticides into the environment, the contamination of global agro-ecosystem and resistance of certain insects and pathogens. The global renewed

Received : 28/07/2020

Accepted : 24/11/2020 interest of botanical pesticides does not leave aside Turkey. Thus, many environmental reports pointed out contaminations in different regions of Turkey by chemical pesticide residues, like lambda-cyhalothrin in some conventional grapes farming in the Aegean region. The use of botanical pesticides like Pyrethrin extracted from Pyrethrum's flowers (Chrysanthemum cinerariifolium) is part of sustainable agriculture goals to reduce the incidence of pests and diseases without any

Keywords: Biopesticides Pyrethrum Sustainable agriculture Tissue culture Vegetative clones alteration to the natural balance. The purpose of this review is to analyse and identify the possibilities of Pyrethrum production in Turkey. Various research works around the world were compiled and some key informants were correlated to existing researches in Turkey. Subsequently, it was found that the Black-Sea region of Turkey has great potential in the growing and industrial production of Pyrethrum by its weather patterns (temperatures, pluviometry and humidity) and soil characteristics. The region has a similar climate with the East-African high-lands well-known for Pyrethrum production. Thus, the country has shown great technological advances and the capacity to produce vegetative and disease-free clones for other ornamental plants by using tissue culture techniques. Therefore, the multiplication of high-quality vegetative clones of Chrysanthemum cinerariifolium and their maintenance can sustain commercial and long term production of Pyrethrum in Turkey.

flavien.shimira@outlook.com ozdemirmsamil@gmail.com http://orcid.org/0000-0003-3382-4068 http://orcid.org/0000-0003-4142-7302 b@senemuur@gmail.com d@ymendi@gmail.com http://orcid.org/0000-0003-2826-4123

http://orcid.org/0000-0002-4587-5156

This work is licensed under Creative Commons Attribution 4.0 International License

\section{Introduction}

It has been reported that many pests, diseases and weeds cause considerable yield losses and genetic resource damages in countless plant productions (Bayrak, 2010). Plants have developed different mechanisms to protect themselves against pests throughout evolution. These mechanisms manifested in plants by some biochemical events and morphological changes. Thus, plants synthesize secondary metabolites which can affect pest behaviour and physiology in different levels of inhibition and toxicity. They initially provide high plant resistance to pathogens and herbivores (Dubey et al., 2010). The most important secondary metabolites synthesized by plants are; alkaloids, glycosides, phenols, terpenoids, tannins, and saponins (Shanker and Solanki, 2000). These synthesized metabolites have been used in agriculture for many years within the scope of pest control and management. Before the discovery and use of synthetic insecticides, it was wellknown that plant-based insecticides play an important role in agriculture. However, synthetic insecticides have been more effective than plant natural insecticides and their effectiveness prevails for a long period which has led to their use for many years. In the past few years, it has been scientifically demonstrated that the unconscious use of synthetic insecticides harms nature, environment and human health. Besides, it was found that pests develop resistance against these insecticides. For these reasons, a renewed interest in plant-based insecticides has reemerged and more studies have been undertaken in this current decade (Güncan and Durmuşoğlu, 2004). Although many plants are known to have an insecticidal effect, very few are used in insecticides production (Isman, 1997). The reason for this is due to the lack of sufficient natural 
resources, lack of standardization and difficulty to obtain a production license as reported by Güncan and Durmuşoğlu (2004).

One of the plants with insecticidal production ability is Pyrethrum (Chrysanthemum cinerariifolium) which is a part of the chrysanthemum genus in the Asteraceae family. It is known to have originated from the Balkan and Eastern coasts of the Adriatic Sea in the Dalmatia region of current Croatia. Its natural habitat can be extended to Bosnia and Herzegovina, Montenegro and to Italy (Zito, 1994; Hitmi et al., 2000a; Grdiša et al., 2009; Tóth et al., 2012; Jongschaap et al., 2018). This perennial ornamental plant is also named Tanacetum cinerariifolium (Trevir.) by some biologists (Li et al., 2014). It is a diploid plant with 18 chromosomes $(2 \mathrm{n}=2 \mathrm{x}=18)$ as reported by Liu and Gao (2007). There are more than 40 species within chrysanthemum genus and to large extent, they are found in East-Asia, particularly in China. Chrysanthemum cinerariifolium is the most popular one. Apart from being used as an efficient insecticide, it is also used in medicine. The plant is characterized by white-yellow flowers that grow to a height of about $60 \mathrm{~cm}$. One particular feature of its flowers is the existence of four different active components like, Cinerin-I, II Pyrethrin-I, II and Jasmolin-I, II which are major insecticidal constituents of pyrethrins. They are especially found in oil glands onto the seed inside the thoroughly packed flower head. In other parts of the plant, Pyrethrin can be also found in small concentrations (Zito et al., 1983; Grdiša et al., 2009; Zhao et al., 2009; Liu and Gao, 2010). As described by Hitmi et al. (2000a), pyrethrins are a set of monoterpene esters with a close similar structure and they result from esterification of two monoterpic acids (pyrethric acid and chrysanthemic acid) with three ketone alcohols (cinerolone, jasmolone and pyrethrolone). In the general effort toward sustainable agriculture, natural insecticides are used as ecological and environment-friendly in the management of agricultural pests. Almost $80 \%$ of natural insecticides produced globally are extracted from Pyrethrum. Thus, Pyrethrum is seen as a legitimate alternative to synthetic insecticides and its extracts contain active compounds that are effective to control different pests including insects and plant diseases' vectors. Apart from Pyrethrum, other well-known botanical pesticides with less damage to the environment are: Neem (Azadirachta indica) pesticides which are systemic and do not leave residue on the crop, Azadirachtin which is non-toxic to mammals, pollinators and fishes, Sabadilla or Cevadilla extracted from Sabadilla lily's seeds (Schoenocaulon officiale), Carvone or Tallent from Caraway's (Carum carvi) essential oil which is often used to protect potatoes in storage against bacterial rotting (Dubey et al., 2011).

In this review, the possibility of Pyrethrum introduction and its adaptability in Turkey are being examined. The rising need for natural insecticides in the country and a cool temperate climate suggest and imply future opportunities in the mass cultivation and growing of Pyrethrum and other plants from which natural insecticides are extracted. Pyrethrum growing has been tested for the first time in Turkey in 1928. It was brought in as seeds from foreign countries and it continued to be cultivated till losing its value among producers despite obtaining high-quality yield. Pyrethrum cultivation was tried again for the second time by the Ministry of Agriculture initiative at Bornova Plant Protection Station and positive results were obtained. By incentive actions by the Turkish government, free saplings were distributed to the producers, unfortunately soon later its production was abandoned for an unknown reason (İpekçioğlu and Aksu, 1943). The active compounds in the Pyrethrum are called "pyrethrins" (Tanker and Tanker, 1990). Since the introduction in many countries of the new legal limitations and requirement of chemical residue tolerance in food, natural substances that are less toxic and do not cause problems gained importance. And doubtlessly a recognition was likewise drawn to the pyrethrins. In Turkey, the Ministry of Agriculture has proposed the production and use of products containing pyrethrin. It was also thought that both the chemical residue problem would be solved and the country would earn economically, but this project could not be implemented for financial reasons (Arslan and Y1lmaz, 1993).

\section{Ecological growing conditions of Pyrethrum}

\section{Climatic Conditions}

In East-Africa and particularly in major producing countries; Kenya and Rwanda, Pyrethrum is always found and grown in highlands with an altitude between 1,500 and 3,000 meters above sea level. In Kenya, highlands are located in the Western regions of the country. In Rwanda, they are located in the Northern regions. Those highlands are suitable for Pyrethrum cultivation and they are characterized by annual rainfall between 1,000 and 1,400 $\mathrm{mm}$. The optimum temperature observed in Kenya lies between 15 and $20^{\circ} \mathrm{C}$. Those temperatures are ideal for maximum photosynthesis. The same ranges are being noticed in Rwanda with an average annual temperature of $15.7^{\circ} \mathrm{C}$ (with a minimum of $11.6^{\circ} \mathrm{C}$ and a maximum of $20^{\circ} \mathrm{C}$ ) (Wandahwa et al., 1996; Kagabo et al., 2013). In Australia, similarities in temperatures with East-Africa are being observed in the main growing state, Tasmania (in the North-West of the state). Tasmania has a warm, temperate maritime climate (four distinct seasons). Temperatures are moderate with $20^{\circ} \mathrm{C}$ maximum during summers and $13^{\circ} \mathrm{C}$ minimum during winters. Rainfall figures are low compared to East-Africa with $750 \mathrm{~mm}$ of annual rainfall (Greenhill, 2007). It was reported that the increase in flower production is related to temperature variations between night time and daytime which are low (under $13^{\circ} \mathrm{C}$ ) and warm $\left(15-20^{\circ} \mathrm{C}\right)$ respectively. Likewise, a rotation between sunny periods and rainfall periods are the suitable conditions for pyrethrum cultivation. It was found that the pyrethrins' content of the flower is affected considerably by temperature. Thus, temperatures above $21^{\circ} \mathrm{C}$ inhibit flowering completely along with frost (extremely low temperatures) that damages Pyrethrum (Kushwaha et al., 2012; Wandahwa et al., 1996).

\section{Soil Conditions}

Pyrethrum is generally grown on fertile and welldrained soils such us loamy soils (derived from volcanic rocks) of Kenya and Rwanda and also krasnozem soils (derived from basalt parent rock) seen in Tasmania (Greenhill, 2007; Mureramanzi and Bizimungu, 2015; Wandahwa et al., 1996). Loamy soils are known for their 
good structure that results in exceptional water infiltration and holdings. The Pyrethrum rooting system can reach a maximum depth of $50 \mathrm{~cm}$. It is generally found within the top $30 \mathrm{~cm}$ of depth. Pyrethrum can grow on soils with great $\mathrm{pH}$ ranges from gravelly to slightly alkaline and also on slightly saline (or calcareous). In Kenya, it is found in soils with $\mathrm{pH}$ values between 4.0 and 6.3 while in India, it is grown in soils of 3.0 to 5.1 of $\mathrm{pH}$ values. It was revealed that Pyrethrum can display soil acidity tolerance between 5.3 and 6.0 of $\mathrm{pH}$. The suitable and recommended soil $\mathrm{pH}$ should be slightly above 5.6 for nutrients availability and accessibility to the crop (Wandahwa et al., 1996). One of Chrysanthenumm cinerariifolium close relatives; Painted Daisy (Pyrethrum roseum or Chrysenthemum roseum) is found in the natural habitat of Erzurum province in the Eastern Anatolia region of Turkey (Tanker and Apaydın, 1973). By assessing soil features in the Erzurum plain of 22 different surface soil samples, Y1ldiz and Bilgin (2008) revealed that the $\mathrm{pH}$ of the soil was between 6.86 and 8.82 . They also determined that the organic matter content ranged between 0.46 and $4.49 \%$ and the lime content ranged between 1.01 and $13.97 \%$. In addition to being found in the mountainous area of Erzunun, Pyrethrum roseum is also naturally blooming in Çorum and Ardanuç, two zones of the Turkish Black Sea region (Davis, 1975). It was determined that in the aforementioned region, known for tea production, the average soil $\mathrm{pH}$ is $4.14,3.72$ and 4.31 in Artvin, Rize and Trabzon provinces respectively (Özyazıcı et al., 2013). Other similar studies were conducted in the same region. For instance, in the study carried out in Trabzon district of Trabzon province, Gür (2019) has revealed that the soil $\mathrm{pH}$ was 5.29, the lime content $(\mathrm{CaCO} 3)$ as $2.12 \%$, total salt rate as $0.016 \%$ and organic matter rate as $2.78 \%$. Likewise, in the Kalkanl mountainous region of Trabzon, a study was conducted by Gedik (2017) and he found that the $\mathrm{pH}$ value of the soil was 5.46 , the organic matter content was $2.20 \%$ and the texture of the soil was silty-loam soils with $0.010 \%$ of salt concentration. In two different studies conducted in the Hayrat district of Trabzon province, it was determined that the $\mathrm{pH}$ of the soil was between 4.65 and 4.96 and the associated amount of organic matter was $4.21 \%$ and $5.34 \%$, respectively. The soil texture was found to be clayloamy (Aydın, 2008; Kuru, 2009). Those types of soil in the Black Sea region can be excellent for Pyrethrum growing due to soil acidity similar to those in countries like Kenya, India, and Rwanda. In an effort to increase considerably Pyrethrum flower yields, Rajeswara Rao et al. (1983) advanced that particularly in acid soils where the availability of phosphorus limits the Pyrethrum yields the application of phosphatic fertilizers up to $120 \mathrm{~kg} \mathrm{P}_{2} \mathrm{O}_{6} \mathrm{ha}^{-1}$ year $^{-1}$ is necessary. Besides, nitrogen and potassium fertilizers don't change Pyrethrum flower yields and pyrethrins concentration.

\section{Global Production of Pyrethrum}

Pyrethrum is used as ornamental and landscape plants for its flamboyant flowers. The flowers of the Pyrethrum plants are appreciated for their pyrethrin extracts. Also, Pyrethrum provides an insecticide widely used worldwide and in Turkey. Natural insecticides are so popular because "insect resistance" has emerged from the use of synthetic insecticides against pests. Environmental damages are also correlated with the use of synthetic insecticides (Göktürk, 2017). Pyrethrum has been produced since time immemorial. Pyrethrum production in the world has been dominated by the following countries: Tanzania, Rwanda, Papua New Guinea, Ecuador, Kenya, and Tunisia. Besides these countries, Italy and Morocco are also important producer countries. While Japan is among the top producers, production has been decreasing in recent years. If we look at the 2020 data, the uncontested world production leader of dried Pyrethrum flowers is Tanzania as shown by the last three years recorded data (Figure 1). In 2018, Tanzanian Pyrethrum was grown to a total production area equal to 13,941 hectares and 7,036 tonnes of dried Pyrethrum flowers were produced (FAO, 2020).

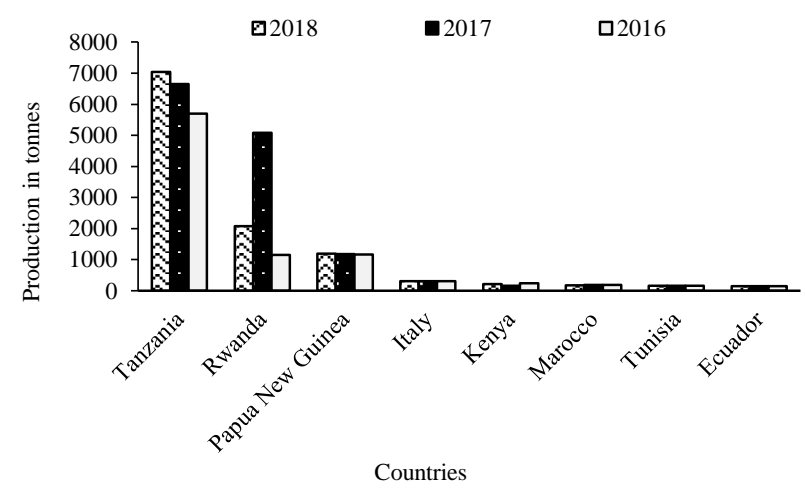

Figure 1. World major producers of dried Pyrethrum flowers in year 2016-2017-2018 (FAO, 2020)

\section{Natural Pyrethrins: Active Compounds in Pyrethrum}

Pyrethrins (Pyrethrin I: $\mathrm{C}_{21} \mathrm{H}_{28} \mathrm{O}_{3}$, pyrethrin II: $\mathrm{C}_{22} \mathrm{H}_{28} \mathrm{O}_{5}$ ) are natural insecticides with a well-known ability to repel insects (Dent, 2000; Shivanandappa and Rajashekar, 2014). Significant concentrations of pyrethrins are usually spotted in flowers. Thus, the dried flower's powders contain natural pyrethrins too (Matsuda et al., 2005). Their repellence is effective in agriculture and horticultural crops to contain numerous vectors of disease such as insects. They have been used successfully against the Mexican bean beetle (Epilachna varivestis) on soybeans. Natural pyrethrins are extracted from the flowers of Pyrethrum and their only burden is that they are less stable biochemically than their synthetic counterparts, pyrethroids. Famous pyrethroids are Deltamethrin and Allethrin (Dent, 2000; Hitmi et al., 2000a). Thus, synthetic pyrethroids have also a disadvantage to be less persistent and promptly biodegradable. A high contact activity is discerned in pyrethroids and they are specifically effective against lepidopterous larvae. Some of the synthetic pyrethroids have moderate toxicity to mammals and they can be particularly harmful to fish and non-target invertebrates (Dent, 2000). Pyrethroids are not specific in their actions and since they stick to leaf surfaces for long periods, disease-causing insects and useful ones are killed. They are also poisonous to honey bees. This makes them less environmentally friendly than pyrethrins (Dubey et al., 2011). Pyrethrins have an instantaneous effect on insects at low concentrations and they can wipe out most insect species (Bailey et al., 2010). Insects are affected by pyrethrins through direct contact, inducing a disruption in 
their nervous system. Transmission of an insect's nerve impulses is terminated through the disruption of sodium and potassium ion-exchange process (Dubey et al., 2011; Shivanandappa and Rajashekar, 2014). Its application in low doses may result in convulsions and brief paralysis of the insect. Subsequently, synergistic interaction with other compounds is required for effectiveness and persistence. So often, synergist such as piperonyl butoxide (PBO) or noctyl bicycloheptane dicarboximide is used (Dubey et al., 2011).

\section{Environmental Impact of Chemical Pesticides in Some Regions of Turkey}

It has been reported that in the regions with a long tradition use of pesticides, it is more likely to found pesticide residues in soils, food and freshwater supply. Thus, this situation leads to a certain and adverse impact on the environment and human health. In the study undertaken by Turgut et al. (2011) in the Aegean region (Izmir, Manisa and Denizli provinces) where the majority of table grapes are produced, it was found that in conventional vineyards pesticide residues were present. The most commonly found, in different proportions and all three provinces were; chlorpyrifos-ethyl, chlorpyrifos-methyl, deltamethrin and lambda-cyhalothrin followed in fewer quantities by Chlorpyrifos-methyl and deltamethrin. Likely, no pesticides were detected in vines from organic vineyards where farmers have adopted integrated pest management. In the risk assessment of those pesticides, only lambda-cyhalothrin exceeded maximum residue level (MRL) of pesticide exposure established by Pesticide Safety Directorate (PSD, York, UK). Other pesticide residues did not exhibit any risk. Other pesticides with negative impacts on the environment are; Organochlorine pesticides (OCPs) and Organochlorine and polychlorinated biphenlys (PCBs). They were globally used since the 1940s as the first synthetic organic pesticides in the control of pests and diseases. Afterward, due to their proven carcinogenetic/mutagenic potential and their toxic effects on animal development, immunological, and reproduction, they were internationally banned from the markets. In Turkey, the same restrictions have been implemented since 1983. Nonetheless, their relatively high concentration presence in some Turkish aquatic environments suggest a continuous usage by farmers (Ayas et al., 2007; Chen et al., 2007; Kalyoncu et al., 2009).

Kalyoncu et al. (2009) carried out a study to investigate the levels of OCPs residues in fish species sold in the central Anatolia province of Konya. Thus, fishes sold in the region are from the seas surrounding Turkey (Aegean Sea, Mediterranean Sea, and the Black Sea) and also from Beyşehir Lake located in 90 kilometers of Konya city. In total fourteen different organochlorine pesticides $(\delta-\mathrm{HCH}$, $\alpha-\mathrm{HCH}, \beta-\mathrm{HCH}, \gamma-\mathrm{HCH}$, Heptachlor, Aldrin, Heptachlor epoxide, $\alpha$-Endosulfan, p-p'-DDE, Dieldrin, Endrin, $\beta$ Endosulfan, p-p'-DDD, p-p'-DDT) were analyzed in eighteen different fish species (bluefish, bonito, common seabream, garfish, gilt head bream, goby, gray mullet, greater amberjack, gurnard, horse mackerel, import mackerel, native mackerel, pilchard, pike perch, red mullet, sea bass, trout and whiting fish) by using gas chromatography with electron capture detector (ECD). The most predominant pesticide contaminants in fish muscles were DDT and HCH. Nearly all samples, detectable levels of $\mathrm{HCH}$, aldrin and heptachlor were discovered. Luckily there was no suggestion of important health risks linked with the consumption of these fishes. All the above-listed risks and contaminations by synthetic pesticides in different regions of Turkey illustrate real needs in the adoption of new agriculture practices which require the use of biopesticides less harmful to the environment.

\section{Pyrethrum in Organic Farming and Pest Management}

The negative effects of chemicals and their impact on human and public health are increasing progressively. Organic farming and good farming practices are being carried out to eliminate the effects of all these negativities on human health and nature. Organic farming constrains the use of synthetic pesticides, hormones, and chemical fertilizers. Thus, it is mainly aiming to restore the natural balance of nature devastated by improper use of chemicals in nature. Furthermore, the use of organic fertilizers in organic farming is recommended to boost the resistance of plants against plant natural enemies and for the preservation of the soil (Hekimoğlu and Altındeğer, 2006). It has been discovered that approximately 1,500 plant species and varieties have an insecticidal effect (Erdoğan, 2013). Nowadays, over 2,000 herbal extracts are obtained from different sections of plants such as roots and seeds. Thus, their effectiveness against pests has been recognized (Öncüer, 2000). Plant-based insecticides are extracts of plants and they are used in agricultural applications, such as; Pyrethrum, Nicotine, Quassine, Capsaicin, Sabadilla, Ryania, Azadirachtin, Rotenone, Garlic, Melia azedarach L., etc. (Table 1). The most used plants for their insecticidal extract are neem (Azadirachta indica) and Chinaberry (Melia azedarach L.) (Erdoğan, 2013). The low residual effect is one of the advantages of using pyrethrins in organic farming. During postharvest applications, for instance, on grains, it has been revealed that in a period of three to four months of storage, $50 \%$ or more of the applied pyrethrins disappear (Gallo et al., 2017). Pyrethrin is environmentally safe and highly biodegradable due to its instability on light, high temperature, oxygen and water. It is recognized and approved in the European Union regulation (EC) No. 834/2007 on organic production and labeling of organic products. Consequently, it is one of the leading and used insecticides in organic farming systems (Grdiša et al., 2009).

\section{Management of pathogens and diseases in Pyrethrum}

Like other ornamental plants, Pyrethrum is not exempt from pests and diseases. Diseases affecting Pyrethrum do prevail in both Pyrethrum production systems; in the lowinput system like in East-Africa which is characterized by limited mechanization and where at certain extent no production inputs (such as herbicides, fungicides, and fertilizers) are used and also in high-input or highly mechanized Pyrethrum production systems like TasmaniaAustralia. Pethybridge et al. (2008) have described major diseases and their related prevalent pathogens (Table 2) affecting mainly production in Tasmania. 
Table 1. Important botanical pesticides and their targeted pests

\begin{tabular}{l|ll}
\hline \multicolumn{1}{c|}{ Plants } & AC & \multicolumn{1}{c}{ Targeted pests } \\
\hline $\begin{array}{l}\text { Neem (Azadirachta } \\
\text { indica) }\end{array}$ & Ansects (Homoptera, Heteroptera, Lepidoptera, & $\begin{array}{l}\text { It acts as repellent, antifeedant, chemosterilant, } \\
\text { and insecticide. It also has fertility reducing } \\
\text { action by preventing egg-laying and disrupting } \\
\text { Orthoptera) }\end{array}$ \\
$\begin{array}{l}\text { Pyrethrum } \\
\begin{array}{l}\text { Chrysanthemum } \\
\text { cinerariifolium })\end{array}\end{array}$ & $\mathrm{P} \quad$ Insects & Effective by contact.
\end{tabular}

cinerariifolium)

sp.), Derris (Derris sp. )

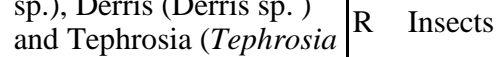

sp.)

Nicotiana tabacum;

Nicotiana rustica;

Nicotiana sylvestris;

Anabasis aphylla

Ryania speciosa

$\mathrm{N}$ Insects

Insects such as; Cydia pomonella Lin., Archips

RY (Lep:Tortricidae), European corn borer (Ostrinia nubilalis) pyralid moths (Lep: Pyralidae).

Sabadilla (Schoenocaulon officinale)

Amargo (Quassia armara

L.) and Jamaican Quassia

(Picrasma excelsa)

(Picrasma excelsa)

Garlic (Allium sativum

L.)

\section{Heteroptera}

Aphids (Hemiptera: Aphididae); Hoplocampa

spp., (Hym: Tenthredinidae); Bemisia tabaci

(Hom: Aleyroridae); Anthonomus pomorum (Col: insects.

Curculionidae)

Insects such as; cowpea weevil (Callosobruchus

maculatus (Col: Bruchidae)), Ephestia kuehniella and Plodia interpunctella (Lep: Pyralidae);

Sitophilus oryzae, S. granarius (Col:

Curculionidae), Plutella xylostella (Lep:

Generally, it is a repellent and effective against

Plutellidae), Trichopis nucleus (Lep: Plutellidae),

Rapae (Lep: Pieridae)

AC: Active compound, A: Azadirachtin, P: Pyrethrins, R: Rotenone, N: Nicotine, RY: Ryania, S: Sabadilla, Q: Quassin, Neoquassin and Picrasmin, Source: (Kılıç 2019; Isman 2006)

Table 2. The main diseases damaging Pyrethrum production

\begin{tabular}{|c|c|c|c|}
\hline $\mathrm{C} / \mathrm{R}$ & Diseases & Pests & Symptoms \\
\hline \multirow{10}{*}{$\mathrm{A} / \mathrm{T}$} & Ray blight & $\begin{array}{l}\text { Phoma ligulicola Baker, Dimock and } \\
\text { Davis v. Arx. var. inoxydablis }\end{array}$ & $\begin{array}{l}\text { Necrosis of the ray florets of the flowers resulting in the death of } \\
\text { flowers and buds. They can also cause necrotic lesions that generally } \\
\text { extend from } 20 \text { to } 30 \mathrm{~mm} \text { on the peduncle of the unopened bud. }\end{array}$ \\
\hline & Sclerotinia crown rot & $\begin{array}{l}\text { Sclerotinia minor Jagger and } S \text {. } \\
\text { sclerotiorum (Lib.) de Bary }\end{array}$ & Crown rot through myceliogenic germination. \\
\hline & Sclerotinia flower blight & S. sclerotiorum & Crown rot through myceliogenic germination. \\
\hline & Botrytis flower blight & Botrytis cinerea Pers. & $\begin{array}{l}\text { Crown rot through myceliogenic germination. Wilting and } \\
\text { death of the entire plant }\end{array}$ \\
\hline & Root rot & Lesion nematodes, Pratylenchus spp. & \\
\hline & Tan spot & Microsphaeropsis tanaceti sp. nov. & There are tan-coloured spots that coalesce around the margins of leaves. \\
\hline & Winter blight & $\begin{array}{l}\text { Alternaria tenuissima (Nees:Fries) } \\
\text { Wiltshire }\end{array}$ & $\begin{array}{l}\text { Necrotic lesions which are colonized by secondary fungi. Small } \\
\text { necrotic spots (generally }<0.5 \mathrm{~cm} \text { in diameter) on leaves. }\end{array}$ \\
\hline & Pink spot & $\begin{array}{l}\text { Caused by Stemphylium botryosum } \\
\text { Wallroth }\end{array}$ & $\begin{array}{l}\text { Lesions on leaves that exhibit necrotic halos surrounded by } \\
\text { pink/brown margins. }\end{array}$ \\
\hline & $\begin{array}{l}\text { Diseases Caused by } \\
\text { Nematodes }\end{array}$ & $\begin{array}{l}\text { Lesion nematodes (Pratylenchus spp.) } \\
\text { particularly } P . \text { crenatus, } P \text {. penetrans and } \\
\text { intermittently } P . \text { neglectus and } P \text {. thornei }\end{array}$ & Significant injury to Pyrethrum \\
\hline & $\begin{array}{l}\text { Tomato spotted wilt } \\
\text { virus (TSWV) infection }\end{array}$ & Tomato spotted wilt virus (TSWV) & Symptomless \\
\hline \multirow{5}{*}{$\mathrm{K}$} & Wilt diseases & $\begin{array}{l}\text { A range of Fusarium spp., but } \\
\text { primarily F. oxysporum Schlechtend. }\end{array}$ & \\
\hline & True bud disease & Ramularia bellunensis Speg & \\
\hline & False bud disease & R. bellunensis & Death of buds \\
\hline & $\begin{array}{l}\text { Diseases Caused by } \\
\text { Nematodes }\end{array}$ & $\begin{array}{l}\text { Root-knot nematode (Meloidogyne } \\
\text { hapla) and lesion nematode } \\
\text { (Pratylenchus penetrans) }\end{array}$ & $\begin{array}{l}\text { Symptoms of root-knot nematode injury include large galls } \\
\text { on roots, hairy and stubby roots. There is also severely } \\
\text { restricted root growth, which can lead to plant death in } \\
\text { susceptible cultivars. }\end{array}$ \\
\hline & Ray Blight & $\begin{array}{l}\text { Phoma ligulicola var. ligulicola and } P \text {. } \\
\text { ligulicola var. inoxydablis. }\end{array}$ & Minor damage on Pyrethrum \\
\hline
\end{tabular}

C/R: Country/ Region, A/T: Australia/Tasmania, K: Kenya, Source: Pethybridge et al. (2008) 
Table 3. Recent developments for in vitro culture of Pyrethrum

\begin{tabular}{|c|c|c|c|c|c|}
\hline $\begin{array}{c}\text { Aim of the } \\
\text { study }\end{array}$ & Explants & $\begin{array}{c}\text { Basal } \\
\text { Medium }\end{array}$ & $\begin{array}{c}\text { Growth } \\
\text { regulators }\end{array}$ & Remarks & Reference \\
\hline $\begin{array}{l}\text { The effects of } \\
\text { growth } \\
\text { regulators } \\
\text { during in } \\
\text { vitro culture }\end{array}$ & Petiole & MS & $\begin{array}{l}\text { 2,4-D, BA \& } \\
\text { NAA }\end{array}$ & $\begin{array}{l}\text { 2,4-D promotes callus growth. } \\
\text { BA and NAA do not affect growth. }\end{array}$ & $\begin{array}{l}\text { Obukosia et } \\
\text { al. (2005) }\end{array}$ \\
\hline $\begin{array}{l}\text { Buds and } \\
\text { roots } \\
\text { induction }\end{array}$ & $\begin{array}{l}\text { Epicotyl } \\
\text { and } \\
\text { hypocotyl }\end{array}$ & $\begin{array}{c}\text { MS } \\
1 / 2 \mathrm{MS}\end{array}$ & $\begin{array}{l}\text { BA \& NAA } \\
\text { IAA \& rooting } \\
\text { powder (ABT) }\end{array}$ & $\begin{array}{l}\text { Variations of NAA concentration have a } \\
\text { significant effect on shoot growth. } \\
0.3 \mathrm{mg} \mathrm{L}^{-1} \text { of BA is efficient for root } \\
\text { induction in the MS medium as well as } \\
0.3 \mathrm{mg} \mathrm{L}^{-1} \text { of NAA. }\end{array}$ & $\begin{array}{l}\text { Liu and Gao } \\
\quad \text { (2007) }\end{array}$ \\
\hline $\begin{array}{l}\text { Direct } \\
\text { organogenesis }\end{array}$ & $\begin{array}{l}\text { Leaf and } \\
\text { petiole } \\
\text { segments }\end{array}$ & $\begin{array}{l}\text { B5 } \\
\text { SH }\end{array}$ & $\begin{array}{l}\text { NAA } \\
\text { NAA }\end{array}$ & $\begin{array}{l}\text { The optimum shoot regeneration was } \\
\text { observed with } 2 \mathrm{mg} \mathrm{L}^{-1} \text { of NAA in the } \\
\text { B5 medium. } \\
4 \mathrm{mg} \mathrm{L}^{-1} \text { of BA and } 2 \mathrm{mg} \mathrm{L}^{-1} \text { of NAA } \\
\text { induce a maximum shoot regeneration in } \\
\text { the MS medium. }\end{array}$ & $\begin{array}{l}\text { Hedayat et } \\
\text { al. (2009) }\end{array}$ \\
\hline $\begin{array}{l}\text { Effectiveness } \\
\text { of different } \\
\text { cytokinins } \\
\text { and auxins }\end{array}$ & $\begin{array}{l}\text { Nodal } \\
\text { explants }\end{array}$ & $\begin{array}{c}\text { MS } \\
1 / 2 \mathrm{MS}\end{array}$ & $\begin{array}{l}\text { 2iP, BAP, KIN } \\
\& \text { TDZ } \\
\text { IBA, NAA \& } \\
\text { 2,4-D }\end{array}$ & $\begin{array}{l}40 \mu \mathrm{M} \text { of BAP are more effective for } \\
\text { micro-shoot proliferation. } \\
\text { A moderate concentration of IBA ( } 10 \\
\mu \mathrm{M}) \text { gives a high number of roots per } \\
\text { explant and considerable root length per } \\
\text { explant. }\end{array}$ & $\begin{array}{l}\text { Lindiro et al. } \\
\quad(2013)\end{array}$ \\
\hline
\end{tabular}

They have also listed subsisting diseases in Kenya. Moreover, among recommendations and tips for all those diseases management, there are;

- The adoption of resistant cultivars to prevent ray blight and wilt diseases. Thus, resistant plants grant a physical and physiological barrier against spore dissemination of some fungal pathogens;

- Vegetative propagation is always advised to counter diseases like Ray Blight caused by Phoma ligulicola;

- Some farming practices such as overhead irrigation and the use of fertilizers mainly in the management of Sclerotinia diseases and Botrytis Flower Blight are not advised;

- Plant density should be decreased by wide spacing planting. Thus, it reduces considerably humidity and leaf wetness period which result in a decline in the rate of disease development;

- The use of nematode-tolerant with a combination of crop rotation from Pyrethrum to cereal crop (like maize) for 1 year period, are efficient in the management of Meloidogyne hapla.

For biological control of nematodes, it was found that two specific arbuscular mycorrhiza fungi (AMF) can be successfully used against Meloidogyne hapla, one of the nematodes devastating Pyrethrum plantations in Kenya. The two isolates of IMF were identified as Glomus etunicatum (Isolate KS18) and Glomus sp. (Isolate KS14). Both isolates have suppressed nematodes population by more than $50 \%$ and egg production up to $75 \%$. They have also decreased disease severity up to $71 \%$ and $57 \%$ by Isolate KS14 (Glomus sp.) and Glomus etunicatum (Isolate KS18) respectively (Waceke et al., 2001).

\section{Micropropagation of Chrysanthemum cinerariifolium}

Micropropagation programs are very useful for commercial planting of Pyrethrum. It is well known that for pyrethrum, the first flowering takes place within 12 to 15 months after seedling. Thus, it is preferable to use vegetative clones for Pyrethrum propagation which gives first flowering within 3 months (Pethybridge et al., 2008). The multiplication of high producing clones of Chrysanthemum cinerariifolium and the maintenance of its clonal purity and with its protection against diseases and environmental stresses are seen and part of classical breeding programs. In vitro clonal multiplication promotes asexual multiplication and its increase propagations of pathogen-free plants. Many researchers have focused their studies on this topic. In vitro multiplication of Pyrethrum has started in the early 1970s. It was an alternative to vegetative propagation by shoot cuttings of Chrysanthemum cinerariifolium which had a low multiplication rate and was vulnerable to root-knot nematodes (Meloidogyne halpa) attacks. Thus, in vitro clonal multiplication promotes asexual multiplication of clones with desirable features and also delivers high propagation rates. As explants, shoot tips and/or axillary buds are used. Besides, formal tissue culture procedures are followed; explants sterilization, the use of a growth medium in which different concentrations of auxin and cytokinin were supplemented. Subsequently in the fourth and/or sixth week, a subculture is performed on the propagation medium (Hitmi et al., 2000a). An in vitro and polyploidy breeding study of $C$. Cinerariifolium was carried out by Liu and Gao (2007) and they successfully obtained autotetraploid plantlets with 36 chromosomes $(2 n=2 x=36)$ by using filter-sterilized colchicine. The obtained polyploid lines were then kept as germplasm 
resources for further research. Thus, polyploid plants are very important in the development of superior varieties due to related biomass increase.

The optimum in vitro callus culture and growth conditions of Pyrethrum have been set up by Hitmi et al. (1998) and they are as follows; a half concentration of standard growth media (MS) calibrated at $5.7 \mathrm{pH}$ with daylight's irradiance intensity equals to $60 \mu \mathrm{mol} . \mathrm{m}^{-2} . \mathrm{S}^{-1}(16$ $\mathrm{h}$ photoperiod) and culture temperature set at $23^{\circ} \mathrm{C}$. The synthesis and aggregation of monoterpenes in the plants are known to be linked to the irradiance intensity, mostly the white light than monochromatic blue $(450 \mathrm{~nm})$ or red $(670$ $\mathrm{nm})$ light. In other words, light is a substantial regulatory factor in the growth of calli and its pyrethrin content accumulation. Other recent studies have shown new developments and optimum conditions for the in vitro growing of Chrysanthemum cinerariifolium (Table 3). Hitmi et al. (2000b) have also described a straightforward and efficient cryopreservation method of Chrysanthemum cinerariifolium shoot tips by using cryoprotectants (such as ABA, DMSO and sucrose), freezing $\left(-196^{\circ} \mathrm{C}\right.$ liquid nitrogen) and thawing (rapid rewarming at $40^{\circ} \mathrm{C}$ ) treatments to increase survivability of in vitro shoot tips. They have obtained satisfying results with $75 \%$ of the shoot tips withstanding cryopreservation. And after which they were fully recovered and propagated on a solid nutrient medium. There was also no loss of biosynthetic activity observed after cryopreservation in Chrysanthemum cinerariifolium plants. Pyrethrins levels remained stable. Hence, a cryopreservation protocol of in vitro plantlet's shoot tips of Pyrethrum was established. Since a long time, Turkish researchers have demonstrated their competence for conducting successfully in vitro and breeding programs for ornamental plants such as; Begonia (Begonia spp.), Cyclamen (Cyclamen ssp.), Rose, Orchids, Carnation, Gypsophila, Lilium, Tulip, Sternbergia, Peonies (Paeonia spp.), Leucojum, Tulipa, Hyacinthella, Hyacinthus and Muscari. (Karaoğlu 2004; Mirici et al., 2005; Doğan- Kalyoncu, 2007; Mendi et al., 2009; Kaya, 2010; Nasircilar et al., 2010; Uranbey et al., 2010; Alp et al., 2013; Gürsan, 2014; Yucesan et al., 2014; Uzun et al., 2014; Curuk et al., 2015; Ozel et al., 2015; Baskaran et al., 2016; Kizil et al., 2016; Hurkan, 2017; Bulut et al., 2019; Kaya et al., 2019). Thus, it confirms the national capacity to produce high quality and disease-free vegetative clones of complex plants such as Chrysanthemum cinerariifolium.

\section{Conclusion}

The promotion and use of Pyrethrum are part of the same goal to attain a durable agriculture system that diminishes chemical residue impacts on the environment. Thus, Integrated Pests and Disease Management (IPDM) and a range of other control strategies for plant protection including biological and physical controls, host plant resistance and decision support tools enter in the broad spectrum of self-regulating ecological systems performed to maintain and reduce pest damages. (Bailey et al., 2010). Pyrethrin insecticidal products have been used in IPDM strategies for years and during the last few years there has been a renewed interest due to high resistance of pests to synthetic pesticides and more restricting environmental and protection laws. Thus, pyrethrins based insecticidal products do have a fast knockdown effect on insects and exhibit also low toxicity to mammals and other warmblooded animals (Rajeswara Rao and Singh, 1982; Grdiša et al., 2009). In the present review, we have demonstrated all technological advances and possibilities of Pyrethrum adaptability in Turkey and we have found that there is a high growing potentiality in the Black-Sea coastal region. This region is high land with high elevations and it is known for its cool climate with average temperature and high humidity. Apart from climate features, another important consideration that we examine is the possibility of mass production of high quality and disease-free vegetative clones of Pyrethrum. For future research, we highly recommend carrying out an adaptability study of several different Kenyan Pyrethrum clones and improved varieties that have been released since the 1960s from different breeding programs by the Kenyan National Pyrethrum and Horticulture Research Station (NPHRS) at Molo. Evidently, they have shown high yielding results (such as Pyrethrins concentration between 1.6 and $2.1 \%$ ) in the highlands of Kenya (with an altitude between 1700 and $2200 \mathrm{~m}$ ). Those are; twelve clones; 4331, Sb/66/107, $\mathrm{Ma} / 70 / 1013, \mathrm{Ks} / 70 / 64, \mathrm{Ma} / 71 / 423, \mathrm{Ks} / 75 / 313, \mathrm{Ks} / 72 / 43$, $\mathrm{L} / 72 / 26, \mathrm{Kr} / 74 / 443, \mathrm{Kr} / 74 / 223, \mathrm{Kr} / 74 / 122, \mathrm{Mo} / 70 / 1124$ and three varieties which are; P4, K218 and K235 (Wambugu and Muthamia, 2009). Formerly, from the clones and/or varieties with high yielding potential of Pyrethrin will be selected for further research.

\section{References}

Alp Ş, Zeybekoğlu E, Salman A, Karaağaçlı M, Özzambak ME. 2013. The breeding and growing importance of Tulip plants in our country. In: Erken K, Pezikoğlu F (editors). V. National Congress of Ornamental Plants, Yalova, Turkey, 6-9 May 2013, Atatürk Horticultural Central Research Institute, pp. 252-256.

Arslan N, Y1lmaz G. 1993. Type of (Pyrethrum sp.) used as a source of the herbal products in reducing pesticide pollution. Ekoloji, 1(6): 3-6.

Ayas Z, Ekmekci G, Ozmen M, Yerli SV. 2007. Histopathological changes in the livers and kidneys of fish in Sariyar Reservoir, Turkey. Environmental Toxicology and Pharmacology, 23(2): 242-249. doi: 10.1016/j.etap.2006. 11.003

Aydin E. 2008. The adaptation of some raspberry and blackberry varieties to Hayrat (Trabzon) ecological zone. MSc Thesis, Institute of Natural and Applied Sciences, Ordu University, Ordu, Turkey.

Bailey A, Chandler D, Grant PW, Greaves J, Prince G, Tatchell M. 2010. Biopesticides: Pest management and regulation. Wallingford (UK): CABI Press. ISBN: 9781845935597.

Baskaran P, Kumari A, Naidoo D, Van Staden J. 2016. In vitro propagation and ultrastructural studies of somatic embryogenesis of Ledebouria ovatifolia. In Vitro Cellular \& Developmental Biology - Plant, 52: 283-292. doi: 10.1007/ s11627-016-9762-9

Bayrak İ. 2010. Investigation of antimicrobial effects of Neotchihatchewia isatidea (Boiss.) Rauschert (Alli bride) and Pyrethrum roseum Bieb. plant extracts plants against some plant pathogenic bacteria. MSc Thesis, Institute of Natural and Applied Sciences, Atatürk University, Ankara, Turkey.

Bulut B, Uranbey S, Ahmed HAA, Caliskan M. 2019. Efficient in vitro bulblet production of endangered Hyacinthella micrantha (Boiss.) Chouard. Japs. The Journal of Animal and Plant Sciences, 29(4): 1135-1141. 
Chen S, Shi L, Shan Z, Hu Q. 2007. Determination of organochlorine pesticide residues in rice and human and fish fat by simplified two-dimensional gas chromatography. Food Chemistry, 104(3): 1315-1319. doi: 10.1016/j.foodchem. 2006.10.032

Curuk P, Sogut Z, Bozdogan E, Izgu T, Sevindik B, Tagipur EM, Teixeira da Silva J, Serce S, Kacar AY, Mendi YY. 2015. Morphological characterization of Cyclamen sp. grown naturally in Turkey: Part I. South African Journal of Botany, 100: 7-15. doi: 10.1016/j.sajb.2015.03.199

Davis PH. 1975. Flora of Turkey and the Aegean islands. Vol. 5. Edinburgh (UK): Edinburgh University Press. ISBN: 0852242808 .

Dent D. 2000. Insecticides. In: Dent D, editor. Insect pest management - 2nd Edition (Vol. 66). Wallingford (UK): CABI Publishing. pp. 81-122. ISBN: 0851993419.

Doğan-Kalyoncu D. 2007. In vitro production and adaptation to field conditions of some wild Tulipa species. PhD dissertation, Institute of Biotechnology, Atatürk University, Ankara, Turkey.

Dubey NK, Shukla R, Kumar A, Singh P, Prakash B. 2010. Prospects of botanical pesticides in sustainable agriculture. Current Science, 98(4): 479-480.

Dubey NK, Shukla R, Kumar A, Singh P, Prakash B. 2011. Global scenario on the application of natural products in integrated pest management Programmes. In: Dubey NK (editor). Natural production in plant pest management. Oxfordshire (UK): CABI. pp. 1-20. ISBN: 9781845936716.

Erdoğan P. 2013. Plant-based insecticides properties and effects on pests. Karaelmas Science and Engineering Journal, 3(2): 14-25. doi: $10.7212 \% 2 F z k u f b d . v 3 i 2.98$

FAO, 2020. Food and Agriculture Organization of the United Nations. FAOSTAT. Available from: http://www.fao.org/ faostat/en/ [Accessed 18 March 2020]

Gallo M, Formato A, Ianniello D, Andolfi A, Conte E, Ciaravolo M, Varchetta V, Naviglio D. 2017. Supercritical fluid extraction of pyrethrins from Pyrethrum flowers (Chrysanthemum cinerariifolium) compared to traditional maceration and cyclic pressurization extraction. The Journal of Supercritical Fluids, 119: 104-112. doi: 10.1016/j.supflu. 2016.09.012

Gedik A. 2017. The effects of different planting periods on plant growth and the yield on broccoli cultivation in Trabzon. MSc Thesis, Institute of Natural and Applied Sciences, Atatürk University, Ankara, Turkey.

Göktürk T. 2017. The effect of Pyrethrum and Bacillus thuringiensis against Pristiphora abietina (Christ, 1791) (Hymenoptera: Tenthredinidae). Artvin Çoruh Üniversitesi Orman Fakültesi Dergisi, 18(1): 83-87. doi: 10.17474/artvinofd.270322

Grdiša M, Carović-Stanko K, Kolak I, Šatović Z. 2009. Morphological and biochemical diversity of Dalmatian Pyrethrum Bip. Agroculturae Conspectus Scientificus, 74(2): 73-80.

Greenhill M. 2007. Pyrethrum production: Tasmanian success story. Chronica Horticulturae, 47(3): 5-8.

Güncan A, Durmuşoğlu E. 2004. An evaluation of plant-based natural insecticides. Hasad Dergisi, 233: 26-32.

Gür, İ. 2019. Performance of some hybrid corn maize cultivars in Trabzon ecological region. MSc Thesis, Institute of Graduate Studies, Isparta University of Applied Sciences, Isparta, Turkey.

Gürsan D. 2014. In vitro reproduction of some lily (Lilium spp.) Species. MSc Thesis, Institute of Natural and Applied Sciences, Uludağ University, Uludağ, Turkey.

Hekimoğlu B, Altındeğer M. 2006. Agricultural methods to be used in organic agriculture and plant protection. Samsun: Republic of Turkey - Samsum Governor's office, Provincial directorate of food agriculture and livestock. Annual report. Available from: https://samsun.tarimorman.gov.tr/Belgeler/ Yayinlar/Kitaplarimiz/Organik_Tarim_ve_Bitki_Koruma\%2 OAcisindan_Organik_Tarimda_Kullanilacak_Yontemler.pdf [Accessed 18 March 2020]
Hedayat M, Abdi G, Khosh-Khui M. 2009. Regeneration via direct organogenesis from leaf and petiole segments of Pyrethrum [Tanacetum cinerariifolium (Trevir.) SchultzBip.]. American-Eurasian Journal of Agricultural and Environmental Sciences, 6(1): 81-87.

Hitmi A, Barthomeuf C, Coudret A. 1998. Production of pyrethrins with Chrysanthemum cinerariaefolium vis. callus culture: Improvement of callus growth and pyrethrin synthesis. Journal of Plant Physiology, 153: 233-236. doi: 10.1016/S0176-1617(98)80072-2

Hitmi A, Coudret A, Barthomeuf C. 2000a. The Production of Pyrethrins by Plant Cell and Tissue Cultures of Chrysanthemum cinerariaefolium and Tagetes Species. Critical Reviews in Biochemistry and Molecular Biology, 35(5): 317-337. doi: 10.1080/10409230091169230

Hitmi A, Barthomeuf C, Sallanon H. 2000b. Cryopreservation of Chrysanthemum cinerariaefolium shoot tips. Journal of Plant Physiology, 156(3): 408-412. doi: 10.1016/S01761617(00)80081-4

Hürkan YK. 2017. Some in vitro studies conducted on Salep orchids in Turkey. International Journal of Innovative Approaches in Science Research, 1(1): 33-46. doi: 10.29329/ijiasr.2017.99.4

İpekçioğlu F, Aksu S. 1943. Researches on natural Pyrethrum. The Tobacco Institute of Turkey Report, Volume III (19431944) Issue: 1-2. pp. 1.

Isman MB. 1997. Neem and other botanical insecticides: Barriers to commercialization. Phytoparasitica, 25(4): 339-344. doi: 10.1007/BF02981099

Isman MB. 2006. Botanical insecticides, deterrents, and repellents in modern agriculture and an increasingly regulated world. Annual Review of Entomology, 51: 45-66. doi: 10.1146/annurev.ento.51.110104.151146

Jongschaap REE, de Vos CH, Jongsma MA. 2018. Feasibility study plant extracts in Rwanda. Wageningen: Wageningen University \& Research. Report WPA-801. Available from: https://research.wur.nl/en/publications/feasibility-studyplant-extracts-in-rwanda-developing-value-chain [Accessed 18 March 2020]

Kagabo DM, Stroosnijder L, Visser SM, Moore D. 2013. Soil erosion, soil fertility and crop yield on slow-forming terraces in the highlands of Buberuka, Rwanda. Soil and Tillage Research, 128: 23-29. doi: 10.1016/j.still.2012.11.002

Kalyoncu L, Agca I, Aktumsek A. 2009. Some organochlorine pesticide residues in fish species in Konya, Turkey. Chemosphere, 74(7): 885-889. doi: 10.1016/j.chemosphere. 2008.11.020

Karaoğlu C. 2004. Rapid in vitro production of Summer snowflake (Leucojum aestivum L.). MSc Thesis, Institute of Natural and Applied Sciences, Atatürk University, Ankara, Turkey.

Kaya AS, Aydinşakir K, Erdal Ş, Kazaz S. 2019. Effects of different applications on the cut flower performance of Gypsophila genotype (GA8). Derim, 36(1): 13-23. doi: 10.16882/derim.2019.449219

Kaya E. 2010. Cultivation and breeding studies on Peonies (Paeonia spp.) of Turkey. In: Sögüt Z, Aydın A, Hocagil M (editors). IV $^{\text {th }}$ Congress of Ornamental Plants, ErdemliMersin, Turkey, 20-22 October 2010, ALATA, pp. 226-238.

Kılıç E. 2019. Agricultural biopesticides that can be substituted to Chemical pesticides in Erzincan. Gaziosmanpaşa Bilimsel Araştırma Dergisi, 8(3): 14-28.

Kizil S, Sesiz U, Khawar KM. 2016. Improved in vitro propagation of Hyacinthus orientalis L. using fruits containing immature zygotic embryos and tender leaf sheath as explants. Acta Scientiarum Polonorum Hortorum Cultus, 15(5): $15-30$.

Kuru S. 2009. Effect of different organic mulch on yield and quality of strawberries in Hayrat (Trabzon). MSc Thesis, Institute of Natural and Applied Sciences, Ordu University, Ordu, Turkey. 
Kushwaha M, Jatav V, Pandey S. 2012. Plant Anacyclus pyrethrum - A Review. Research Journal of Pharmacognosy and Phytochemistry, 4(3): 164-170.

Li J, Jongsma MA, Wang CY. 2014. Comparative analysis of pyrethrin content improvement by mass selection, family selection and polycross in Pyrethrum [Tanacetum cinerariifolium (Trevir.) Sch.Bip.] populations. Industrial Crops and Products, 53: 268-273. doi: 10.1016/ j.indcrop.2013.12.023

Lindiro C, Kahia J, Asiimwe T, Mushimiyimana I, Waweru B, Kouassi M, Koffi E, Kone S, Sallah PY. 2013. In vitro regeneration of Pyrethrum (Chrysanthemum cinerariaefolium) plantlets from nodal explants of in vitro raised plantlets. International Journal of Application or Innovation in Engineering \& Management, 2(7): 207-213.

Liu Z, Gao S. 2007. Micropropagation and induction of autotetraploid plants of Chrysanthemum cinerariifolium (Trev.) Vis. In Vitro Cellular \& Developmental Biology Plant, 43: 404-408. doi: 10.1007/s11627-007-9085-y

Liu Z, Gao S. 2010. Research on pollen grains of tetraploid lines and diploid control line of Chrysanthemum Cinerariifolium (Trev.) Vis. Agricultural Science \& Technology - Hunan, 11(5): 151-154.

Matsuda K, Kikuta Y, Haba A, Nakayama K, Katsuda Y, Hatanaka A., Komai K. 2005. Biosynthesis of pyrethrin I in seedlings of Chrysanthemum cinerariaefolium. Phytochemistry, 66(13): 1529-1535. doi: 10.1016/j.phytochem. 2005.05.005

Mendi YY, Curuk P, Kocaman E, Unek C, Eldogan S, Gencel G, Cetiner S. 2009. Regeneration of begonia plantlets by direct organogenesis. African Journal of Biotechnology, 8(9): 1860-1863.

Mirici S, Parmaksiz İ, Özcan S, Sancak C, Uranbey S, Sarıhan EO, Gümüşçü A, Gürbüz B, Arslan N. 2005. Efficient in vitro bulblet regeneration from immature embryos of endangered Sternbergia fischeriana. Plant Cell, Tissue and Organ Culture, 80: 239-246. doi: 10.1007/s11240-004-3016-y

Mureramanzi J, Bizimungu G. 2015. Pyrethrum in Rwanda. Acta Horticulturae, 1073: 39-42. doi: 10.17660/ActaHortic. 2015.1073.3

Nasırcılar AG, Mirici S, Karagüzel Ö, Eren Ö, Baktır İ. 2010. In vitro propagation of endemic and endangered Muscari mirum from different explant types. Turkish Journal of Botany, 35: 37-43. doi: 10.3906/bot-0907-90

Obukosia SD, Kimani E, Waithaka K, Mutitu E, Kimani PM. 2005. Effects of growth regulators and genotypes on pyrethrum in vitro. In Vitro Cellular \& Developmental Biology - Plant, 41: 162-166. doi: 10.1079/IVP2004620

Öncüer C. 2000. Agricultural pest control methods and pesticides (4th Edition). Adnan Menderes Üniversitesi Yayınları, 13: 333.

Ozel CA, Khawar KM, Unal F. 2015. Factors affecting efficient in vitro micropropagation of Muscari muscarimi Medikus using twin bulb scale. Saudi Journal of Biological Sciences, 22(2): 132-138. doi: 10.1016/j.sjbs.2014.09.007

Özyazıcı MA, Dengiz O, Aydoğan M. 2013. The changes in agricultural soil features of tea plantations and their area of distribution. Toprak Su Dergisi, 2(1): 23-29.

Pethybridge SJ, Hay FS, Esker PD, Madison W, Gent DH, Wilson CR, Groom T, Nutter FW. 2008. Diseases of Pyrethrum in Tasmania : Challenges and Prospects for Management. Plant Disease, 92(9): 1260-1272. doi: 10.1094/PDIS-92-9-1260

Rajeswara Rao BR, Singh SP. 1982. Spacing and nitrogen studies in Pyrethrum (Chrysanthemum cinerariifolium). Journal of Agricultural Science, 99(2): 457-459. doi: 10.1017/ S0021859600030264

Rajeswara Rao BR, Singh SP, Prakasa Rao EVS. 1983. N, P and $\mathrm{K}$ fertilizer studies in Pyrethrum (Chrysanthemum cinerariifolium). Journal of Agricultural Science, 100(2): 509-511. doi: 10.1017/S0021859600033682

Shanker C, Solanki KR. 2000. Botanical insecticides: A historical perspective. Asian Agrihistory, 4(2): 21-30.
Shivanandappa T, Rajashekar Y. 2014. Mode of action of plantderived natural insecticides. In: Singh D (editor). Advances in Plant Biopesticides. Lucknow/Uttar-Pradesh, India: Springer India; p. 323-345. ISBN: 978-81-322-2005-3 (Print) 978-81-322-2006-0 (Online).

Tanker M, Apaydin R. 1973. Research on Pyrethrins and Other Chemical Compounds Existing in Pyrethrum roseum (M. B.). Journal of Faculty of Pharmacy of Ankara University, 3(1): 149-186. doi: 10.1501/Eczfak_0000000195

Tanker M, Tanker N. 1990. Pharmacognosy. Journal of Faculty of Pharmacy of Ankara University, 2(65): 301-302.

Tóth S, Stricík M, Týr S, Veres T. 2012. The possibilities of Slovakian Pyrethrum production. Pesticidi I Fitomedicina, 27(3): 245-252. doi: 10.2298/pif1203245t

Turgut C, Ornek H, Cutright TJ. 2011. Determination of pesticide residues in Turkey's table grapes: The effect of integrated pest management, organic farming, and conventional farming. Environmental Monitoring and Assessment, 173: 315-323. doi: 10.1007/s10661-010-1389-4

Uranbey S, Ipek A, Caliskan M, Dundar E, Cocu S, Basalma D, Guneylioglu H. 2010. In vitro bulblet induction from bulb scales of endangered ornamental plant Muscari azureum. Biotechnology \& Biotechnological Equipment, 24(2): 18431848. doi: 10.2478/V10133-010-0024-4

Uzun S, Parmaksiz I, Uranbey S, Mirici S, Sarihan EO, Ipek A., Kaya MD, Gürbüz B, Arslan N, Sancak C, Khawar KM, Özcan S. 2014. In vitro micropropagation from immature embryos of the endemic and endangered Muscari muscarimi Medik. Turkish Journal of Biology, 38: 83-88. doi:10.3906/biy-1307-52

Waceke JW, Waudo SW, Sikora R. 2001. Suppression of Meloidogyne hapla by arbuscular mycorrhiza fungi (AMF) on Pyrethrum in Kenya. International Journal of Pest Management, 47(2): 135-140. doi: 10.1080/ 09670870151130633

Wambugu, PW, Muthamia, ZK. 2009. The state of plant genetic resources for food and agriculture in Kenya. Nairobi: Kenya Agricultural Research Institute, National Genebank of Kenya. Available from: http://www.fao.org/pgrfa-gpa-archive/ken/ kenya2.pdf [Accessed 18 March 2020]

Wandahwa P, van Ranst E, van Damme P. 1996. Pyrethrum (Chrysanthemum cinerariifolium Vis.) cultivation in West Kenya: origin, ecological conditions and management. Industrial Crops and Products, 5(4): 307-322. doi: 10.1016/S0926-6690(96)00032-5

Yildiz N, Bilgin N. 2008. Determination of Phosphorus and Potassium content in the soils of Erzurum plain by using Neubauer seedling method. Atatürk Üniversitesi Ziraat Fakültesi Dergisi, 39(2): 159-165.

Yucesan BB, Cicek F, Gurel E. 2014. Somatic embryogenesis and encapsulation of immature bulblets of an ornamental species, grape hyacinths (Muscari armeniacum Leichtlin ex Baker). Turkish Journal of Agriculture and Forestry, 38: 716-722. doi: 10.3906/TAR-1308-81

Zhao HE, Liu ZH, Hu X, Yin JL, Li W, Rao GY., Zhang ZH, Huang CL, Anderson N, Zhang QX, Chen JY. 2009. Chrysanthemum genetic resources and related genera of Chrysanthemum collected in China. Genetic Resources and Crop Evolution, 56(7): 937-946.

Zito SW. 1994. Chrysanthemum cinerariaefolium (Pyrethrum): In vitro culture and production of pyrethrins and other secondary metabolites. In: Bajaj YPS (editor). Medicinal and Aromatic Plants VI. Biotechnology in Agriculture and Forestry, vol 26. Berlin: Springer Berlin Heidelberg. pp. 5668. ISBN 978-3-642-57970-7

Zito SW, Zieg RG, Staba EJ. 1983. Distribution of pyrethrins in oil glands and leaf tissue of Chrysanthemum cinerariaefolium. Planta Medica, 47(4): 205-207. doi: $10.1055 / \mathrm{s}-2007-969986$ 